\title{
Assessment of Soil Health under Protected Cultivation by Soil Quality Indexing and Variability Analysis
}

\author{
Debalina Biswas $^{1 *}$, J.N. Raina ${ }^{2}$ and Kishore Kumar Das ${ }^{3}$ \\ ${ }^{1}$ ICAR RC for NEH Region, Umiam, Ri-Bhoi, Meghalaya-793103, India \\ ${ }^{2}$ Division of Soil Science and Water Management, Dr. Y.S. Parmar University of Horticulture \\ and Forestry, Nauni, Solan, HP-123230, India \\ ${ }^{3}$ Department of Horticulture, S.K Rajasthan Agriculture University, \\ Bikaner- 334006, Rajasthan, India \\ *Corresponding author
}

\section{A B S T R A C T}

Soil quality assessment is of paramount importance to know the appropriate management practices to be adopted for sustainable crop production. Sustainability of intensive agriculture system is intimately linked to maintenance of soil health. Present study was

\section{Keywords}

Soil health,

Protected

cultivation,

Himachal Pradesh,

Soil quality

indexing

Article Info

Accepted:

20 March 2017

Available Online:

10 April 2017 undertaken to investigate the impact of intensive cultivation on soil health under polyhouses located in Bilaspur, Solan and Sirmaur districts of Himachal Pradesh. Studies reveal that the bulk density ranged from 1.09 to $1.13 \mathrm{Mg} \mathrm{m}^{-3}$. The particle density varied between 2.25 to $2.31 \mathrm{Mg} \mathrm{m}^{-3}$, whereas the porosity ranged from 49.47 to 51.09 per cent. The CEC values fell in the range of 14.70 to $15.00 \mathrm{meq} . / 100 \mathrm{~g}$. The soil reaction was noted to be neutral (7.08 to 7.34) and EC values were in safe limits $\left(<0.8 \mathrm{dS} \mathrm{m}^{-1}\right)$. The organic carbon content varied from 1.76 to 2.00 per cent. The available $\mathrm{N}, \mathrm{P}$ and $\mathrm{K}$ ranged from 246.1 to $264.8,49.5$ to 61.9 and 587.1 to $682.5 \mathrm{~kg} \mathrm{ha}^{-1}$, respectively. The exchangeable Ca and $\mathrm{Mg}$ were found to be adequate and sulphur content $\left(15.21\right.$ to $\left.16.99 \mathrm{mg} \mathrm{kg}^{-1}\right)$ was found moderate in the soils. Available $\mathrm{Zn}, \mathrm{Fe}, \mathrm{Cu}$ and $\mathrm{Mn}$ were medium to high in availability, both under polyhouse and open field conditions. The microbial biomass ranged from 322.65 to $385.343 \mu \mathrm{g} \mathrm{g}^{-1}$, falling under medium range for categorizing soil health. In light of the soil health index values $36.7,46.7$ and 16.6 per cent of samples were categorized under the very high, high and medium soil health, respectively under polyhouse conditions. Such values for open field condition were noted to be 10,70 and 20 per cent, respectively. Soil health was found to be affected by the management practices adopted by the farmers and the degree of manure and fertilizer usage over a period of time considerably.

\section{Introduction}

Soil health is defined as the continued capacity of a soil to function as a vital living system, by recognizing that it contains biological elements that are key to ecosystem function within land-use boundaries, to sustain plant and animal productivity, maintain or enhance water and air quality, and promote plant and animal health (Doran and Zeiss, 2000). Soil health is extremely valuable but highly vulnerable. The increased cropping intensity had been found to accentuate changes such as rapid increase in degradation 
of soil physical condition, deterioration of nutrient status and changes in the number and composition of soil organisms (Ayoub, 1999). People in developed countries have realized that over dosing of agricultural soils with fertilizers, pesticides and other toxic chemicals have paved the way for soil ill health and pollution of the environment (Govindarajan and Thangaraju, 2001; Muhammad et al., 2013). In India also, adverse effects on soil health and soil quality primarily arise from nutrient imbalance, soil contamination and injudicious application of fertilizers, pesticides and herbicides. The agricultural land availability is shrinking day by day due to intense industrialization. Therefore, it has almost become a compulsion to increase the per unit yield levels from the available land under agriculture which however, can be achieved by using modern technology such as cultivation in polyethylene-houses. The research data on production potential of protective cultivation for horticultural crops revealed that yield of horticultural crops can be increased from 20 to 30 per cent. This shows that protected cultivation has tremendous scope to improve the economy of the growers as well as fulfill the demand for horticultural crops throughout the year from the small piece of land (Baghel et al., 2003). Protected cultivation has emerged as an alternative to open field production. Among the various floricultural crops carnation (Dianthus caryophyllus Linn.) is cultivated widely inside polyhouses especially, in the low and mid hill zones. The present research therefore was focused on carnation. It is pertinent to add that intensive cultivation of flowers under polyhouse condition has lead to injudicious and excess use chemical inputs, resulting in adverse physico-chemical condition of soil (Huang and Zhang, 2004). Therefore, soil quality assessment inside the polyhouses is of paramount importance to study the impact of intensive cultivation on soil health under polyhouses. An index of soil health should be standardized that integrates physical, chemical and biological properties of soils into a single numeral that serves as the soil's "key indicator" for typical soil health.

\section{Materials and Methods}

The study was carried out in three districts of Himachal Pradesh i.e. Bilaspur, Solan and Sirmaur for assortment of necessary information about cultivation practices, cropping patterns and problems prevailing in the polyhouses growing carnation. Ten polyhouses growing flower crops were selected at random from each district and soil samples were collected from inside the polyhouse as well as from the open field adjacent to the polyhouse.

A total number of 60 soil samples (0 to 20 $\mathrm{cm})$, were collected from different locations with the help of spade and auger, thereafter samples were air dried, crushed in a wooden pestle and mortar, passed through $2 \mathrm{~mm}$ sieve and were subjected to the following analytical procedures. The obtained data of physical, chemical and biological characteristics were subjected to student t-test for variability analysis (Gomez and Gomez, 1984).

Selecting appropriate indicators is the foundation of soil health assessment. A total of 19 indicators were considered, including the physical indicators such as bulk density, particle density and porosity. Chemical indicators such as $\mathrm{pH}$, electrical conductivity (EC), organic carbon, bicarbonate, chloride, soil nutrient indicators such as available nitrogen, available phosphorous, available potassium, calcium, magnesium, sulphur, zinc, iron, manganese, copper and biological indicators such as microbial biomass were used for soil health assessment under protected and open field conditions (Table 1). Soil property threshold levels, interpretations, 
and associated soil index values are listed in table 2. The individual index values for all the soil properties measured were summed to give a total SQI (Michael et al., 2007).

Total SQI $=\Sigma$ individual soil property index values

The maximum value of the total SQI is 28 if all 19 soil properties are measured. The total SQI is then expressed as a percentage of the maximum possible value of the total SQI for the soil properties that are calculated:

SQI, \% = (total SQI / maximum possible total SQI for properties measured) $\times 100$

\section{Results and Discussion}

Table 4 represent that the calculated values through student t-test when compared with table value at 5\% level of significance (2.101) revealed that there was significant difference in the electrical conductivity, phosphorous, zinc, copper, particle density and bicarbonate content in different locations of Bilaspur. Gao et al., (2012) also documented that soil physical and chemical properties in newly-built greenhouse such as contents of available phosphorus and available micronutrients in soil increased after one growing season of tomato.

Table.1 Methods employed for estimating important soil properties

\begin{tabular}{|c|c|c|}
\hline Particular & Method employed & Reference(s) \\
\hline Bulk Density & Core tube method & \\
\hline Particle Density & Pycnometer method & \\
\hline Porosity & Empirical formula [(1-BD*/PD) $\left.)^{* *} \mathrm{X} 100\right]$ & \\
\hline $\mathrm{pH}$ & $\begin{array}{l}\text { 1:2 soil:water suspension, with the help of } \\
\text { digital } \mathrm{pH} \text { meter }\end{array}$ & Jackson, (1973) \\
\hline $\begin{array}{l}\text { Electrical } \\
\text { Conductivity }\end{array}$ & $\begin{array}{l}\text { 1:2 soil:water suspension, with the help of } \\
\text { digital EC meter }\end{array}$ & Jackson, (1973) \\
\hline Organic carbon & Rapid titration method & Walkley and Black (1934) \\
\hline $\mathrm{CaCO}_{3}$ & Rapid titration method & Puri,(1930) \\
\hline $\begin{array}{l}\text { Cation Exchange } \\
\text { Capacity }\end{array}$ & $\begin{array}{l}\text { Sodium and ammonium acetate, Centrifuge } \\
\text { method }\end{array}$ & Bower et.al. (1952) \\
\hline $\mathrm{CO}_{3}, \mathrm{HCO}_{3}^{-}, \mathrm{Cl}^{-}$ & Rapid titration method & Reitemeier (1943) \\
\hline Available N & Alkaline potassium permanganate method & Subbiah and Asija (1956) \\
\hline Available P & Olsen's method & Olsen et al., (1954) \\
\hline $\begin{array}{lr}\begin{array}{l}\text { Available } \\
\text { calcium } \\
\text { magnesium }\end{array} & \text { and } \\
\end{array}$ & Ammonium acetate method & Merwin and Peech (1951) \\
\hline $\begin{array}{l}\text { Available sulphur } \\
\left(\mathrm{SO}_{4}-\mathrm{S}\right)\end{array}$ & Turbidimetric method $\left(0.15 \% \mathrm{CaCl}_{2}\right)$ & Williams and Steinbergs (1959) \\
\hline $\begin{array}{lr}\text { DTPA Extractable } \\
\text { Zinc, } \\
\text { Manganese, Copper }\end{array}$ & 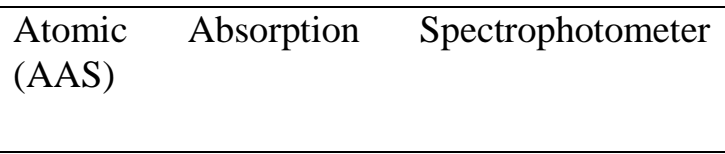 & Lindsay and Norvell (1978) \\
\hline Microbial biomass & Soil Fumigation-Extraction Method & Vance et al., (1987) \\
\hline
\end{tabular}


Table.2 Soil health index values and associated soil property threshold values and interpretations

\begin{tabular}{|c|c|c|c|}
\hline Parameter & Level & Interpretation & Index \\
\hline \multirow[t]{2}{*}{ Bulk density $(\mathrm{g} / \mathrm{cc})$} & $>1.5$ & Possible adverse effect & 0 \\
\hline & $<1.5$ & Adverse effect unlikely & 1 \\
\hline \multirow[t]{2}{*}{ Porosity (\%) } & $>40$ & Adverse effect unlikely & 1 \\
\hline & $<40$ & Possible adverse effect & 0 \\
\hline \multirow[t]{8}{*}{ Soil pH } & $<3.0$ & Severe acidic (no plant will grow in this environment & -1 \\
\hline & $3.01-4$ & Strongly acidic & 0 \\
\hline & $4.01-5.5$ & Moderately acidic & 1 \\
\hline & $5.51-6.8$ & Slightly acidic & 2 \\
\hline & $6.81-7.2$ & Near neutral & 2 \\
\hline & $7.21-7.5$ & Slightly alkaline & 1 \\
\hline & $7.5-8.5$ & Moderately alkaline & 1 \\
\hline & $>8.5$ & Strongly alkaline & 0 \\
\hline \multirow{3}{*}{$\begin{array}{l}\text { Bicarbonate } \\
(\mathrm{meq} / \mathrm{l})\end{array}$} & $<2.5$ & Usual range for most of the crop & 2 \\
\hline & $2.5-5.0$ & Satisfactory & 1 \\
\hline & $>5.0$ & High- Toxic to plants & 0 \\
\hline \multirow[t]{3}{*}{ Chloride (meq/l) } & $<5.0$ & Usual range for most of the crop & 2 \\
\hline & $5.0-10$ & Satisfactory & 1 \\
\hline & $>10$ & High- Toxic to plants & 0 \\
\hline \multirow[t]{3}{*}{$\mathrm{EC}(\mathrm{dS} / \mathrm{m})$} & $<0.8$ & Low & 2 \\
\hline & $0.8-2.5$ & Medium & 1 \\
\hline & $>2.5$ & High & 0 \\
\hline \multirow[t]{3}{*}{ Organic carbon $(\%)$} & $<0.5$ & Low-indicate loss of $\mathrm{C}$ from erosion and other processes. & 0 \\
\hline & $0.5-1.5$ & Moderate- adequate level & 1 \\
\hline & $>1.5$ & High- Excellent buildup of OC with all possible benefits. & 2 \\
\hline \multirow{3}{*}{$\mathrm{N}(\mathrm{kg} / \mathrm{ha})$} & $<280$ & Low -Possible deficiencies & 0 \\
\hline & $280-560$ & Moderate-adequate level for most of plant & 1 \\
\hline & $>560$ & High-excellent reserve & 2 \\
\hline \multirow[t]{3}{*}{$\mathrm{P}(\mathrm{kg} / \mathrm{ha})$} & $<12.4$ & Low-Possible deficiencies & 0 \\
\hline & $12.4-24.2$ & Moderate-adequate level for most of plant & 1 \\
\hline & $>24.2$ & High-excellent reserve & 2 \\
\hline
\end{tabular}




\begin{tabular}{|c|c|c|c|}
\hline \multirow[t]{3}{*}{$\mathrm{K}(\mathrm{kg} / \mathrm{ha})$} & $<98.6$ & Low-Possible deficiencies & 0 \\
\hline & $98.6-280.0$ & Moderate-adequate level for most of plant & 1 \\
\hline & $>280.0$ & High-excellent reserve & 2 \\
\hline \multirow[t]{2}{*}{$\mathrm{Ca}\left(\mathrm{cmol}\left(\mathrm{p}^{+}\right) / \mathrm{kg}\right)$} & $<1.5$ & Low-possible deficiency & 0 \\
\hline & $>1.5$ & High- Excellent reserve & 1 \\
\hline \multirow[t]{2}{*}{$\operatorname{Mg}\left(\mathrm{cmol}\left(\mathrm{p}^{+}\right) / \mathrm{kg}\right)$} & $<1.0$ & Low-possible deficiency & 0 \\
\hline & $>1.0$ & High- Excellent reserve & 1 \\
\hline \multirow[t]{2}{*}{$\mathrm{SO}_{4}-\mathrm{S}(\mathrm{ppm})$} & $<10$ & Low-possible deficiency & 0 \\
\hline & $>10$ & $\begin{array}{l}\text { High- may indicate gypsum soils atmospheric } \\
\text { deposition. }\end{array}$ & 1 \\
\hline \multirow[t]{2}{*}{$\mathrm{Zn}(\mathrm{ppm})$} & $<0.6$ & $\begin{array}{l}\text { Low-possible deficiency in calcareous and sandy } \\
\text { soil. }\end{array}$ & 0 \\
\hline & $>0.6$ & Sufficient & 1 \\
\hline \multirow[t]{2}{*}{$\mathrm{Fe}(\mathrm{ppm})$} & $<4.5$ & Low-possible deficiency & 0 \\
\hline & $>4.5$ & High- Excellent reserve & 1 \\
\hline \multirow[t]{2}{*}{$\operatorname{Mn}(\mathrm{ppm})$} & $<3.5$ & Low-adverse effect unlikely & 0 \\
\hline & $>3.5$ & Sufficient & 1 \\
\hline \multirow[t]{2}{*}{$\mathrm{Cu}(\mathrm{ppm})$} & $<0.2$ & $\begin{array}{l}\text { Low-indicate possible deficiencies in organic, } \\
\text { calcareous or sandy soils. }\end{array}$ & 0 \\
\hline & $>0.2$ & Sufficient & 1 \\
\hline \multirow[t]{2}{*}{$\mathrm{CEC}\left(\mathrm{cmol}\left(\mathrm{p}^{+}\right) / \mathrm{kg}\right)$} & $<10$ & Low-possible deficiency of exchangeable cations & 0 \\
\hline & $>10$ & $\begin{array}{l}\text { High- Excellent reserve of OC, exchangeable } \\
\text { cations }\end{array}$ & 1 \\
\hline \multirow{3}{*}{$\begin{array}{l}\text { Microbial } \\
\text { biomass } \\
(\mu \mathrm{g} / \mathrm{g})\end{array}$} & $<300$ & Low & 0 \\
\hline & $300-400$ & Medium & 1 \\
\hline & $>400$ & High & 2 \\
\hline
\end{tabular}

The soil health of polyhouse and open condition were categorized following the rating given by Gugino et al., (2009) (Table 3). 
Table.3 Rating of soil according to soil health index

\begin{tabular}{|l|l|l|}
\hline Sl. no. & Interpretation & SHI \\
\hline 1. & $>\mathbf{8 5 \%}$ & Very high \\
\hline 2. & $\mathbf{7 0 - 8 5 \%}$ & High \\
\hline 3. & $\mathbf{5 5 - 7 0 \%}$ & Medium \\
\hline 4. & $\mathbf{4 0 - 5 5 \%}$ & Low \\
\hline 5. & $<40 \%$ & Very low \\
\hline
\end{tabular}

Table.4 Status of soil health indicators under different conditions of the selected districts

\begin{tabular}{|c|c|c|c|c|c|c|c|c|c|}
\hline \multirow[b]{2}{*}{ Particular } & \multicolumn{3}{|c|}{ Bilaspur } & \multicolumn{3}{|l|}{ Solan } & \multicolumn{3}{|c|}{ Sirmaur } \\
\hline & Poly (mean) & $\begin{array}{l}\text { Open } \\
\text { (mean) }\end{array}$ & t-cal & $\begin{array}{l}\text { Poly } \\
\text { (mean) }\end{array}$ & $\begin{array}{l}\text { Open } \\
\text { (mean) }\end{array}$ & t-cal & $\begin{array}{l}\begin{array}{l}\text { Poly } \\
\text { (mean) }\end{array} \\
\end{array}$ & $\begin{array}{l}\text { Open } \\
\text { (mean) }\end{array}$ & t-cal \\
\hline BD $\left(\mathrm{Mg} \mathrm{m}^{-3}\right)$ & 1.08 & 1.16 & NS & 1.03 & 1.14 & NS & 1.06 & 1.2 & NS \\
\hline PD $\left(\mathrm{Mg} \mathrm{m}^{-3}\right)$ & 2.19 & 2.50 & NS & 2.24 & 2.26 & NS & 2.27 & 2.25 & NS \\
\hline Porosity (\%) & 51.49 & 50.69 & NS & 53.24 & 48.24 & NS & 52.46 & 46.49 & NS \\
\hline $\begin{array}{l}\text { CEC(meq./100 } \\
\text { g) }\end{array}$ & 15.66 & 14.33 & NS & 14.92 & 14.37 & NS & 14.89 & 14.61 & NS \\
\hline pH & 7.12 & 7.57 & NS & 7.15 & 7.33 & NS & 7.06 & 7.1 & NS \\
\hline$E C\left(d S m^{-1}\right)$ & 0.77 & 0.53 & $2.14 *$ & 0.44 & 0.23 & $2.12^{*}$ & 0.43 & 0.24 & NS \\
\hline OC (\%) & 1.86 & 1.66 & NS & 1.97 & 1.70 & NS & 2.50 & 1.50 & $2.29 *$ \\
\hline $\mathbf{N}\left(\mathrm{kg} \mathrm{ha}^{-1}\right)$ & 250.57 & 241.7 & NS & 268.13 & 251.51 & NS & 277.45 & 252.17 & NS \\
\hline$P\left(\mathrm{~kg} \mathrm{ha}^{-1}\right)$ & 80.64 & 43.23 & $2.42 *$ & 85.57 & 34.27 & $2.48^{*}$ & 66.3 & 32.7 & NS \\
\hline $\mathrm{K}\left(\mathrm{kg} \mathrm{ha}^{-1}\right)$ & 760.03 & 482.38 & NS & 752.86 & 488.66 & NS & 802.03 & 563.02 & NS \\
\hline Ca $\operatorname{cmol}\left(\mathrm{p}^{+}\right) / \mathrm{kg}$ & 8.76 & 13.17 & NS & 17.08 & 11.47 & NS & 14.24 & 13.56 & NS \\
\hline $\begin{array}{l}\mathrm{Mg} \\
\mathrm{cmol}\left(\mathrm{p}^{+}\right) / \mathrm{kg}\end{array}$ & 0.98 & 1.02 & NS & 1.01 & 1.06 & NS & 0.97 & 1.13 & $2.29 *$ \\
\hline$S\left(\mathrm{mg} \mathrm{kg}^{-1}\right)$ & 19.44 & 14.54 & NS & 14.69 & 16.47 & NS & 13.63 & 16.79 & NS \\
\hline $\mathrm{Zn}\left(\mathrm{mg} \mathrm{kg}^{-1}\right)$ & 3.32 & 2.63 & $2.21 *$ & 2.98 & 2.43 & NS & 3.44 & 2.94 & NS \\
\hline $\mathrm{Fe}\left(\mathrm{mg} \mathrm{kg}^{-1}\right)$ & 4.68 & 6.00 & NS & 7.78 & 7.67 & NS & 9.38 & 5.86 & NS \\
\hline $\mathrm{Cu}\left(\mathrm{mg} \mathrm{kg}^{-1}\right)$ & 7.25 & 2.89 & $2.43^{*}$ & 2.76 & 4.63 & NS & 3.44 & 2.32 & NS \\
\hline $\operatorname{Mn}\left(\mathrm{mg} \mathrm{kg}^{-1}\right)$ & 5.79 & 3.41 & NS & 7.75 & 9.48 & NS & 10.26 & 9.41 & NS \\
\hline $\begin{array}{l}\text { Chloride(cmol } \\
(\mathrm{p}+) / \mathrm{kg})\end{array}$ & 0.04 & 0.03 & NS & 0.05 & 0.04 & NS & 0.06 & 0.05 & NS \\
\hline $\begin{array}{l}\text { Bicarbonate } \\
(\mathrm{cmol}(\mathrm{p}+) / \mathrm{kg})\end{array}$ & 1.57 & 0.46 & $3.01^{*}$ & 1.3 & 0.74 & NS & 1.07 & 0.63 & NS \\
\hline MB $\left(\mu g^{-1}\right)$ & 393.63 & 377.04 & NS & 372.41 & 354.76 & NS & 335.08 & 310.21 & NS \\
\hline
\end{tabular}


Table.5 Soil Health Index in polyhouses and open condition of different district

\begin{tabular}{|c|c|c|c|c|c|c|c|c|c|}
\hline \multicolumn{10}{|c|}{ Soil Health Index (\%) } \\
\hline S.No & Bilaspur & Poly & Open & Solan & Poly & Open & Sirmaur & Poly & Open \\
\hline 1. & Sakred-1 & 78.57 & 64.29 & Oachghat & 82.14 & 78.57 & Kanogata & 78.57 & 82.14 \\
\hline 2. & Sakred-2 & 71.43 & 75.00 & Mahog-1 & 82.14 & 82.14 & Paviana & 85.71 & 82.14 \\
\hline 3. & Jukhala & 85.71 & 78.57 & Mahog-2 & 89.29 & 82.14 & Chakhal-1 & 85.71 & 82.14 \\
\hline 4. & Noa & 67.86 & 78.57 & Budlayana & 85.71 & 82.14 & Chakhal-2 & 85.71 & 78.57 \\
\hline 5. & Nauni & 75.10 & 85.71 & Patrar & 89.29 & 89.29 & Kasar & 85.71 & 75.12 \\
\hline 6. & Patialog & 78.57 & 67.86 & Kathar & 85.71 & 64.29 & Kotli & 89.29 & 96.43 \\
\hline 7. & Thandora & 78.57 & 71.43 & Sodi & 78.57 & 78.57 & Talon & 67.86 & 67.86 \\
\hline 8. & Lanjhata-1 & 60.71 & 71.43 & Basal & 85.71 & 75.00 & Dhamla & 78.57 & 78.57 \\
\hline 9. & Lanjhata-2 & 71.43 & 75.20 & Riwalsar-1 & 57.14 & 60.71 & Rajgarh & 75.00 & 71.43 \\
\hline 10. & Ghumarwin & 82.14 & 82.14 & Riwalsar-2 & 64.29 & 75.00 & Nohra & 78.57 & 67.86 \\
\hline & MEAN & 75.01 & 75.02 & MEAN & 79.99 & 76.78 & MEAN & 81.07 & 78.23 \\
\hline
\end{tabular}

Fig.1 The study area (maps of Solan, Sirmaur and Bilaspur districts)

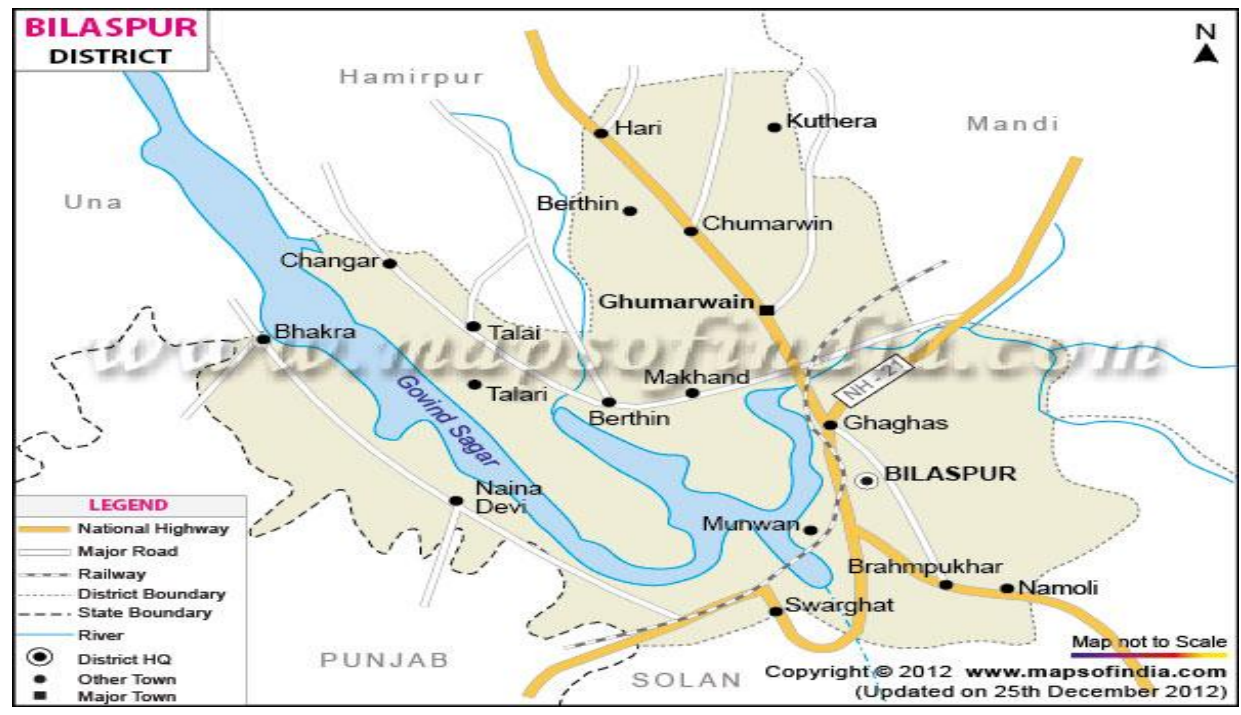

Source: www.mapsofindia.com 


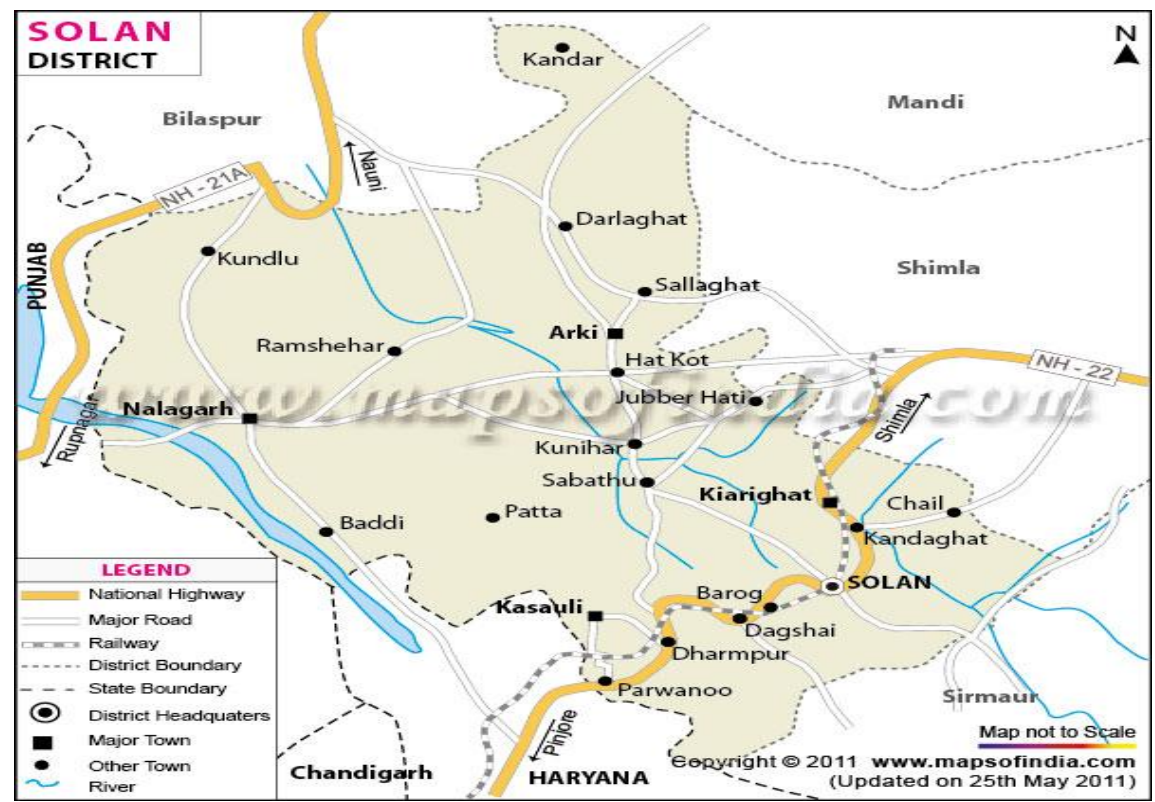

Source: www.mapsofindia.com

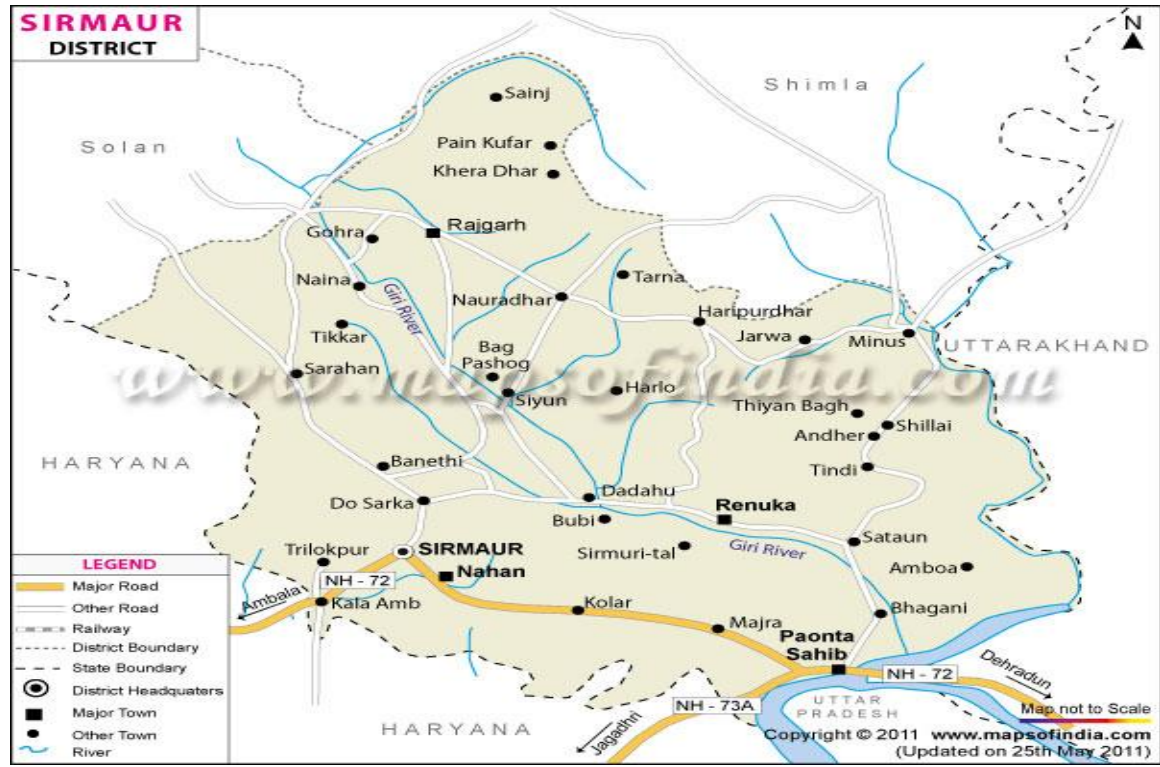

Source: www.mapsofindia.com

The electrical conductivity in the surface soil layer also increased to some degree. But the other soil health indicators ware found non-significant. In Solan district electrical conductivity and phosphorous show significant difference between polyhouse and open condition at 5\% level of significance as compared to other soil health indicators which were found statistically non significant. Lou et al., (2012) also reported that soil electrical conductivity increased significantly in comparison with open field condition mainly due to the reckless application of nitrogenous fertilizer with higher rate in the greenhouses. Similar findings were also reported by several 
researchers (Cao et al., 2012, Gao et al., 2012). Organic carbon and magnesium content were statistically significant at 5\% level of significance, under polyhouse and open condition in different locations of Sirmaur district (Table 4). This might have caused by the long-term combined application of inorganic fertilizers along with organic manure mainly FYM, plant residues and vermicompost (Cao et al., 2012, Tida et al., 2011). Remaining indicators registered no significant variation. This consequence might have taken place due to the fact that at different districts, the locations are situated in the nearby area. These significant indicators emerged through variability analysis can plausibly be of immense help for soil and plant sampling in the studied area for further study as it gives a better idea of the soil health status.

Soil health index value in Bilaspur varied from 60.71-85.71 per cent (Table 5). The soil health index under protected cultivation of Jukhala and Lanjhata-1 areas registered maximum (85.71) and minimum (60.71) values, respectively. Under open field condition however, soils of Nauni and Sakred-1 areas registered highest $(85.71 \%)$ and lowest $(64.29 \%)$ values, respectively. According to soil health rating 10, 70 and 20 per cent of surveyed polyhouse in Bilaspur district were rated as very high, high and medium in soil health status, respectively. Even as under open field condition, 10\%, $70 \%$ and $20 \%$ soils were in very high, high and medium soil health conditions, respectively. In Solan district soil health index value fell in the range of 57.14 to 89.29 per cent (Table 5). The soil health index in the polyhouse of Mahog-2, Patrar registered the highest value of $89.29 \%$ and Riwalsar-1 (57.14\%) registered the lowest value, respectively. However, under open field conditions Patrar (89.29\%) and Riwalsar-1 (60.71\%) registered the maximum and minimum values, respectively (Table 5). According to soil health rating, 50, 30 and 20 percent of surveyed polyhouse in Solan district were rated as very high and high and medium in soil health status, respectively. However, under open condition, $10 \%, 70 \%$ and $20 \%$ soils were in very high, high and medium soil health conditions, respectively. Soil health index value in Sirmaur district varied from 67.86-96.43 per cent. The soil health index in the polyhouse of Kotli and Talon registered maximum $(89.29 \%)$ and minimum $(67.86 \%)$ values, respectively.

Under open field condition however, Kotli $(96.43 \%)$ registered the highest value while, Talon and Nohra registered the lowest value of $67.86 \%$ (Table 5). According to soil health rating 50, 40 and 10 per cent of surveyed polyhouse in Sirmaur district were considered as very high and high and medium in soil health status, respectively. However, under open condition, 10, 70 and 20 per cent soils were in very high, high and medium soil health conditions, respectively. Taking into account all the selected indicators, it was found that amongst the polyhouses $36.66,46.67$ and 16.67 percent have very high, high $\&$ medium soil health, respectively. Whereas, under open field conditions $10 \%, 70 \%$ and $20 \%$ have very high, high and medium soil health, respectively. Soil health was found to be influenced by the management practices adopted by the farmers and the degree of manure and fertilizer usage over a period of time. It has been observed that soil indicators viz. $\mathrm{pH}, \mathrm{N}, \mathrm{K}, \mathrm{Ca}, \mathrm{Mg}, \mathrm{S}$, micronutrients and chloride had less impact on soil health; while EC, phosphorus, organic carbon, porosity, bicarbonates and microbial biomass greatly varied in the present study. Similar finding have earlier been reported by Juan et al. (2013). 
It can be recapitulated that health status of soil under polyhouse condition is at higher level as compared to corresponding open field conditions. This may be accredited to proper cropping pattern and relatively lesser use of harmful chemical inputs, which sustain the quantity and quality of soil organic matter and improve physical and chemical status of the soil. Adequate application of fertilizers along with farmyard manure may further improve soil nutrient status and soil organic carbon content. The soil indicators like $\mathrm{pH}, \mathrm{N}, \mathrm{K}$, $\mathrm{Ca}, \mathrm{Mg}, \mathrm{S}$, micronutrients and chloride had less effect on soil health, while, EC, phosphorus, organic carbon, porosity and microbial biomass significantly influenced the soil health both under polyhouse and open field conditions. Status of soil under polyhouse condition as compared to corresponding open field conditions was found to be healthier. Adequate application of fertilizers along with farmyard manure may further improve soil nutrient status and soil organic carbon content. There is a necessity for screening of soil health status under polyhouse production system at regular intervals and well-timed adoption of counteractive measures to retain good soil health for sustainable productivity.

\section{References}

A.O.A.C. 1970. Official and tentative methods of analysis. Association of official Analytical Chemists. William Star Wetglad, Washington.

Ayoub A T (1999). Fertilizer and the environment. Nutrient Cycling in Agroecosystem. 55(2): 117-121.

Baghel B S, Gupta M and Tiwari R. 2003. Potential and prospects of protective cultivation of horticultural crops. Proceedings of All India on Seminar Potential and Prospects for Protected Cultivation, organized by the Institute of Engineers, Ahmednagar, December 12-
13,2003.

Bower C A, Gschwend F B, Reitemeier R F and Fireman M. 1952. Exchangeable cation analysis of saline and alkali soils. Soil Science 73: 251-261.

Cao Q W, Zhang W H, Li L B, Sun Y L, Sun X L, Ai X Z. 2012. Distribution and accumulation characteristics of nutrients in solar greenhouse soil in Ji'nan, Shandong Province of East China. National Center for Biotechnology Information. 23(1):115-24.

Doran, J W and Zeiss M R. 2000. Soil health and sustainability: managing the biotic component of soil quality. Applied Soil Ecology 15:3-11

Gao J J, Bai X L, Zhou B, Zhou J B and Chen Z J. 2012. Soil nutrient content and nutrient balances in newly-built solar greenhouses in northern China. Nutr. Cycl. Agroecosyst. 94:63-72

Gomez K A and Gomez A A. 1984. Statistical procedure for agricultural research, 2nd Ed. John Wiley and Sons, Inc., New York, USA. 680p.

Govindarajan K and Thangaraju M. 2001. Azospirilium- a potential inoculant for horticultural crops. South Indian Horticulture 49: 223-235.

Gugino B K, Idowu O J, Schindelbeck R R, VanEs H M, Wolfe D W, MoebiusClune B N, Thies J E and Abawi G S. 2009. Cornell Soil Health Assessment Training Manual, Edition 2.0, Cornell University, Geneva, NY.

Huang Yi and Zhang Yu-long. 2004. Soil degradation problem in greenhouse and control countermeasures. Chinese Journal of Soil Science 02.

Jackson M L. 1967. Soil Chemical Analysis. Oxford and IBH Publishing House, Bombay. pp38.

Jackson M L. 1973. Soil Chemical Analysis. Prentice Hall of India Pvt. Ltd., New Delhi.

Juan Bi Chun, Chen Lou, Zhen Wang Jun and Zhou Dong. 2013. Quantitative Assessment of Soil Health under Different Planting Patterns and Soil 
Types Pedosphere 23(2): 194-204

Lindsay W H and Norvell W A. 1978. Development of DTPA soil test for Zn, $\mathrm{Fe}, \mathrm{Mn}$ and $\mathrm{Cu}$. Soil Science Society of American Journal 42: 420-428.

Lou Y, Xu M, He X, Duan Y and Li L. 2012. Soil nitrate distribution, $\mathrm{N} 2 \mathrm{O}$ emission and crop performance after the application of $\mathrm{N}$ fertilizers to greenhouse vegetables. Soil Use and Management. 28: 299-306

Merwin H D and Peech M. 1951. Exchangeability of soils potassium in the silt and clay fractions as influenced by the nature of the complimentary exchangeable cations. Soil Science Society of American Proceedings 15: 125-128.

Michael A C, O'Neil, Katherine P Perry, Charles H. 2007. Soil vital signs: A new Soil Quality Index (SQI) for assessing forest soil health. Res. Pap. RMRS-RP65WWW. Fort Collins, CO: U.S. Department of Agriculture, Forest Service, Rocky Mountain Research Station. 12 p.

Muhammad A M, Shahid H, Tariq A and Muhammad A. 2013. Sustainable agriculture through integrated soil fertility management on degraded lands. Developments in Soil Salinity Assessment and Reclamation. pp 759768

Olsen S R, Cole C V, Watanable F S and Dean L A. 1954. Estimation of available posphorous in soil by extraction with sodium bicarbonate. USDA Circular 939: 1-19.

Puri A N. 1930. New method of estimating

\section{How to cite this article:}

Debalina Biswas, J.N. Raina and Kishore Kumar Das. 2017. Assessment of Soil Health under Protected Cultivation by Soil Quality Indexing and Variability Analysis. Int.J.Curr.Microbiol.App.Sci. 6(4): 2546-2556. doi: https://doi.org/10.20546/ijcmas.2017.604.297 total carbonates in soils. Indian Agricultural Research Institute Pusa Bulletin 206. pp. 7.

Reitemeier R F. 1943. Semimicroanalysis of saline soil solution. Indus and Engin. Chem., Analyst. Ed. 15: 393-402.

Subbiah B V and Asija G L. 1956. Rapid method for estimation of available nitrogen in soils. Current Science 25: 259-260.

Tida G, Nie S, Jinshui W, Jianlin S, He'ai X, Chengli $\mathrm{T}$, Danfeng $\mathrm{H}$, Yun $\mathrm{H}$ and Iwasaki K. 2011. Chemical properties, microbial biomass and activity differ between soils of organic and conventional horticultural systems under greenhouse and open field management: a case study. Journal of Soils and Sediments.11(1) 25-36

Vance E D, Brookes P C and Jenkinson D S. 1987. Microbial biomass measurements in forest soils: The use of the chloroform fumigation incubation method for strongly acid soils. Soil Biol. Biochem 19: 697-702.

Vogel A I. 1978. Text book of quantitative inorganic analysis. Richard clay, The Chances press Ltd., Britain.

Walkley A and Black I A. 1934. Examination of the method for determining soil organic matter and a proposed modification of the chromic acid titration method. Soil Sci. 37:29-38.

Willliams C H and Steinbergs S. 1959. Soil sulphur fractions as chemical indices of available sulphur in some Australian soils. Journal of Agriculture Research 10 (3): 340-352. 